\title{
Comparative study on use of CD4 T cell count and plasma P24 antigen concentration in antiretroviral therapy monitoring for HIVIAIDs patients in Kano, Nigeria
} Abdulrazak Yahaya ${ }^{* 1}$, Auwal Yola ${ }^{2}$ and Musa Babashani ${ }^{3}$

\author{
Address: ${ }^{1} \mathrm{HIV} / \mathrm{Imm}$ unology Unit, Department of Pathology, MMSH, Kano, Nigeria, ${ }^{2}$ Department of Medicine M.A. Wase Specialist Hospital, \\ Kano, Nigeria and ${ }^{3}$ Department of Medicine Aminu Kano Teaching Hospital, Kano, Nigeria \\ * Corresponding author
}

from 2006 International Meeting of The Institute of Human Virology

Baltimore, USA. 17-2I November, 2006

Published: 2I December 2006

Retrovirology 2006, 3(Suppl I):P67 doi:I0.I I86/I742-4690-3-SI-P67

(C) 2006 Yahaya et al; licensee BioMed Central Ltd.

\section{Background}

Monitoring antiretroviral therapy through CD4T-cell count and viral load or reverse transcriptase assessment is used in developed countries. However, cost implication, demand of sophisticated equipments, high level manpower need made such technology impracticable in most of the African laboratory settings. Developing countries having the fewer specialized diagnostic facilities and more affected by the disease requires reliable and cost effective monitoring options (W.H.O., 2003). Research works carried out on various viral parameters such as p24 antigen, plasma RNA, rapid reverse transcriptase detection method were put into trials; p24 antigen emerged as the best possible option for African laboratories use (because of its simplicity and affordability) and correlates well with viral load and can be used as an alternative to viral load monitoring (Schupbach, et al., 2003).

\section{Materials and methods}

A total of fifty-two HIV/AIDS patients receiving care at Murtala Muhammad Specialist Hospital Kano, Nigeria were used in carrying out this study and twenty two were females while thirty were males. Seventeen were about to start antiretroviral therapy at the onset of this study (group I), while thirty five were already receiving HAART (group II). $5 \mathrm{mls}$ of blood samples were collected into EDTA bottles from the subjects at the onset of the study and after three months. Three months later effect of antiretrovirals (HAART) was monitored for both groups by determining the mean gain in CD4 T-cell count and drop in plasma p24 antigen.

\section{Results}

CD4T-cell count range for subjects who were about to start HAART at the beginning this study (group I) was significantly low: $30-190$ cells $/ \mathrm{ml}$ of blood ( $\mathrm{p}>0.05$ ), while subjects already on HAART at the beginning of this study (group II) have shown increased CD4 T-cell count, ranging from low to normal level after three months therapy with HAART: 102-1060 cells per ml of blood (p < $0.05)$.

Males studied in this work have CD4T-cell count of 44190 cells per $\mathrm{ml}$ of blood in group I, while those in group II have range of 113-1060 cells per Ml of blood sample. Females in group I have CD4T-cell count range of 30-175 cells per $\mathrm{ml}$ of blood sample, in group II their CD4T-cell count increased to a range of 102-924 cells per ml of blood. Plasma p24 antigen concentration range of 124$307.8 \mathrm{pg} / \mathrm{ml}$ and $127.8-237 \mathrm{pg} / \mathrm{ml}$ was recorded in females and males in group I. Treated groups (group II) showed an appreciable serum concentration of p24 antigen, in males to be $12.1-149.2 \mathrm{pg} / \mathrm{ml}$, while in females the range was $6.9-184.2 \mathrm{pg} / \mathrm{ml}$

\section{Conclusion}

The problems of cost, high level manpower need associated with primer HIV testing like viral load which are the 
bottle neck to their use in developing countries like Nigeria can be tackled through embracing an alternative testing algorithm like P24 antigen level in the plasma of patients receiving antiretroviral therapy. This could provide another simple method to assess antiretroviral therapy, rather than looking at CD4T-cell count alone which some of them are latently infected but still being counted as if they are normal cells.

Publish with Bio Med Central and every scientist can read your work free of charge

"BioMed Central will be the most significant development for disseminating the results of biomedical research in our lifetime. " Sir Paul Nurse, Cancer Research UK

Your research papers will be:

- available free of charge to the entire biomedical community

- peer reviewed and published immediately upon acceptance

- cited in PubMed and archived on PubMed Central

- yours - you keep the copyright

Submit your manuscript here:

http://www.biomedcentral.com/info/publishing_adv.asp 